\title{
CIRCULATING RNA IN BLOOD PLASMA AS DIAGNOSTIC TOOL FOR CLINICAL ONCOLOGY
}

\author{
Lolomadze EA $\bowtie$, Kometova W, Rodionov W
}

Kulakov National Medical Research Center for Obstetrics, Gynecology and Perinatology, Moscow, Russia

\begin{abstract}
One of the key challenges facing today's oncology is the discovery of early predictors of malignant neoplasms in patients' biological samples. Liquid biopsy is a noninvasive diagnostic technique based on the detection and isolation of tumor cells, tumor-derived nucleic acid and exosomes circulating in the blood plasma of cancer patients. There is a plethora of research studies of circulating tumor DNA in patients with MN. The active proliferation of tumor cells occurs in the backdrop of altered gene expression. The presence of tissue-specific transcripts in the circulating RNA fraction suggests that levels of circulating RNA reflect the development of the primary tumor. We think that cell-free RNA circulating in the blood plasma is a promising molecular biomarker for early cancer detection.

Keywords: circulating nucleic acids, blood plasma, circulating tumor cells, circulating RNA, miRNA, biomarkers, oncology

Funding: the study was conducted under the state assignment AAAA-A18-118053190012-9 (Development of assays for early diagnosis of breast and ovarian
\end{abstract} cancers based on the analysis of RNA circulating in the peripheral blood).

Acknowledgements: we thank the Center for Precision Genome Editing and Genetic Technologies for Biomedicine of Pirogov Russian National Medical Research University (Moscow, Russia) for their help in interpreting the data and analyzing some of the results.

Author contribution: Lolomadze EA — literature analysis and preparation of the manuscript draft; Kometova W, Rodionov W - editing and manuscript revision

$\square$ Correspondence should be addressed: Elena A. Lolomadze

Oparina, 4, Moscow, 117997; 6332424@gmail.com

Received: 23.06.2020 Accepted: 26.06.2020 Published online: 30.06.2020

DOI: $10.24075 /$ brsmu.2020.040

\section{АНАЛИЗ ВНЕКЛЕТОЧНОЙ ФРАКЦИИ РНК ПЛАЗМЫ КАК ИНСТРУМЕНТ ДИАГНОСТИКИ В ОНКОЛОГИИ}

\author{
Е. А. Лоломадзе , В. В. Кометова, В. В. Родионов
}

Национальный медицинский исследовательский центр акушерства, гинекологии и перинатологии имени В. И. Кулакова, Москва, Россия

\begin{abstract}
Одна из ключевых задач современной онкодиагностики - поиск ранних предикторов злокачественных новообразований (ЗНО) при анализе наиболее доступных видов биоматериала. Жидкостная биопсия представляет собой одну из неинвазивных методик и включает в себя обнаружение и выделение циркулирующих опухолевых клеток, циркулирующих опухолевых нуклеиновых кислот и экзосом из плазмы крови у пациентов со злокачественными заболеваниями. Множество работ посвящено исследованию внеклеточной фракции ДНК при ЗНО. Вместе с тем активную пролиферацию трансформированных клеток при развитии опухолей сопровождают значительные изменения экспрессии определенных генов. Обнаружение тканеспецифичных транскриптов в составе внеклеточной РНК плазмы крови (ВНРНК) позволяет предположить, что представленность циркулирующих в плазме РНК связана с развитием патологического процесса непосредственно в первичном очаге. На наш взгляд, внРНК плазмы крови представляют практическую ценность в качестве молекулярно-генетических маркеров ранней диагностики в онкологии.
\end{abstract}

Ключевые слова: циркулирующие нуклеиновые кислоты, плазма крови, циркулирующие опухолевые клетки, вНРНК, микроРНК, биомаркеры, онкология Финансирование: исследование выполнено в рамках работ по Государственному заданию №АААА-А18-118053190012-9 «Разработка тест-системы для ранней диагностики рака молочной железы и рака яичников на основе анализа свободно циркулирующих (внеклеточных) РНК периферической крови".

Благодарности: мы благодарим Центр высокоточного редактирования и генетических технологий для биомедицины, Университет Пирогова (Москва, Россия) за помощь в интерпретации данных и анализе некоторых результатов.

Вкладе авторов: Е. А. Лоломадзе-анализ литературныхисточников и написание текста; В. В. Кометова, В. В. Родионов — написание и редактирование статьи.

$\bigotimes$ Для корреспонденции: Елена Анатольевна Лоломадзе ул. Опарина, 4, г. Москва, 117997; 6332424@gmail.com

Статья получена: 23.06.2020 Статья принята к печати: 26.06.2020 Опубликована онлайн: 30.06.2020 DOI: $10.24075 /$ vrgmu.2020.040

Diagnostic tests known as liquid biopsies hold promise for the future of cancer screening. They are capable of detecting tumor-derived biomarkers in the blood serum of patients with malignant neoplasms (MN), including circulating tumor cells, circulating tumor DNA or RNA, and exosomes. Liquid biopsy samples can be analyzed using a few different types of analysis, such as quantification of individual analytes, including proteins, identification of nucleic acid sequences of the analyte, profiling DNA methylation, etc. [1]. The analysis of cell-free nucleic acids circulating in the blood plasma allows assessing the genetic heterogeneity of the tumor in response to anti-cancer therapy [2, 3].

It is known that apoptotic and necrotic cells release DNA or RNA fragments and exosomes (membrane-bound encapsulated subcellular structures containing proteins and nucleic acids derived from tumor cells) into the bloodstream [4]. From the early stages of carcinogenesis through the advanced stages of metastatic spread, tumor cells accumulate specific mutations and epigenetic modifications; these changes can be spotted by the analysis of cell-free nucleic acids.

\section{Analysis of circulating DNA}

The analysis of circulating DNA has been used in clinical oncology for over 20 years to aid the diagnosis and monitoring of the following cancers: lung [5, 6], head and neck [7], esophageal [8], breast [9], hepatic [10], colon [11], pancreatic [12], renal [13], and others. As a rule, the tests look for the presence of mutations in oncogenes, tumor suppressor genes and microsatellites $[6,9,13]$. Similarly, DNA methylation analysis has some diagnostic and prognostic value and can be employed for monitoring tumor growth $[8,14]$. Quantitative aberrations of circulating DNA have been also reported in other pathologies besides $\mathrm{MN}$, including preeclampsia [15], fetal chromosomal aneuploidy [16], and pernicious vomiting of pregnancy [17]. 


\section{Analysis of circulating mRNA}

The active proliferation of tumor cells and tumor evolution are accompanied by the pronounced changes in the abundance of various transcripts, some of which, like mRNA, can be quantified by RT-PCR [18]. RT-PCR was successfully used to measure the levels of circulating mRNA transcripts of housekeeping genes in the blood samples of healthy individuals and cancer patients [19]. Circulating RNA was also studied in patients with melanoma [20-22], follicular lymphoma [23], breast [22, 24-28], colon [23, 29], hepatic [30], esophageal [21], nasopharyngeal [31], thyroid [22], prostate [40, 41], lung [32] and other cancers. However, research into cell-free RNA is not limited to malignancies: its levels were investigated in patients with trauma [33, 34], diabetic myopathy [35], and pregnancy (fetal mRNA) [36].

A study demonstrated a statistically significant difference in hTERT mRNA levels between patients with early stages of breast cancer $(\mathrm{BC})$ and healthy individuals. The presence of hTERT mRNA in the blood plasma of BC patients was affected by the surgical removal of the tumor [25]. However, it is unlikely that hTERT is a BC-specific marker because its concentrations also change in patients with melanoma and thyroid cancer [22]. The levels of hMAM mRNA expression in the blood plasma were correlated with unfavorable prognosis and poor survival in BC patients [26]. In another study, patients with BC were shown to have elevated Bmi-1 mRNA as compared to healthy donors [27]. According to a recent report, LincRNA-ROR (long intergenic non-protein coding RNA regulator of reprogramming) might be a potential biomarker of $\mathrm{BC}$; considering that its plasma levels decline in the postoperative vs. preoperative period, this marker can be exploited to monitor a BC patient's condition [28].

It is reported that serum MMP-9 is elevated in the late stages of ovarian cancer and correlates with poor prognosis, which suggests the potential prognostic value of this biomarker [37]. The presence of circulating HMGA2 ctRNA may also be a promising tool for the diagnosis and monitoring of ovarian cancer [38].

Patients with advanced prostate cancer were shown to have higher levels of circulating cBMP6 mRNA than those with the localized lesion. At the same time, H3K27me3 is characterized by inverse distribution, and its levels are significantly lower in patients with metastatic prostate cancer than in those with early stages of the disease. Thus, post-treatment levels of circulating cBMP6 and H3K27 mRNAs are discriminators between metastatic and localized prostate cancer [39]. Levels of hTERT mRNA in the blood plasma might be another biomarker for distinguishing between localized and locally advanced prostate cancer [40].

\section{Analysis of exosome composition}

Ever more attention has been paid to the research into the extracellular vesicles (exosomes and microvesicles) secreted by the tumor that are thought to promote invasion and metastatic spread [41, 42].

Extracellular vesicles are specialized membrane organoids secreted by most cell types; they contain various molecules, including RNA, lipids, proteins, and metabolites [43, 44]. At present, extracellular vesicles are being increasingly recognized as mediators of cell-to-cell communication, transporting mRNA from cancer to normal cells across the extracellular matrix [45, 46].

Microvesicles contain microRNA, different types of long RNA, including mRNA, circular RNA and long non-coding RNA $[47,48]$. RNA profiles of extracellular vesicles isolated from healthy individuals and patients with hepatocellular carcinoma are significantly different [48].

\section{Analysis of circulating microRNA}

MicroRNA comprises a group of non-coding regulatory RNA consisting of approximately 22 nucleotides and playing an essential role in the regulation of gene expression [49]. Relatively high stability makes microRNA a more advantageous biomarker than mRNA. MicroRNA is found both inside and outside exosomes $[50,51]$ and is highly stable due to its association with argonaute proteins [52] or lipoprotein complexes, like high density lipoproteins [53].

There were attempts to analyze circulating microRNA in patients with lymphoma [54] and in the plasma/serum samples of patients with prostate cancer [55]. Plasma levels of miR-26a can be indicative of ovarian epithelial cancer [56]. Patients with $\mathrm{BC}$ have significantly elevated concentrations of 4 different microRNAs (miR-148b, miR-376c, miR-409-3p, miR-801) [57]. Increased levels of miR-16, miR-21, and miR-451 and low miR145 concentrations were observed in the plasma of patients with BC [58]. Used in combination, miR-145 and miR-451 were shown to be the best biomarkers of $\mathrm{BC}$, helping to discriminate between $\mathrm{BC}$ patients and healthy individuals or patients with other cancers.

\section{Challenges and limitations}

Although the analysis of circulating RNA has impressive potential for the application in different fields of medicine, it is not free from drawbacks. Errors occurring during target amplification can affect the results of RNA quantification, especially when dealing with small numbers of analytes [59]. Some discrepancies might be due to the different efficacy of the applied reverse-transcriptase amplification techniques observed for different microRNA and mRNA sequences in different molecular environments. Therefore, PCR-free strategies for detecting circulating RNA seem to be most attractive $[60,61]$.

Today, most diagnostic approaches based on the analysis of circulating RNA have relatively low specificity and sensitivity [62]. Their improvement requires further large-scale prospective cohort studies.

\section{CONCLUSIONS}

The analysis of circulating RNA in cancer patients has a high diagnostic and prognostic value. The informative value of liquid biopsy can be considerably improved by separately analyzing the exosomal and cell-free circulating RNAs, including microRNA. Standardization of sample collection, circulating RNA extraction and the analysis of the obtained results will help to reduce the number of false-negative and false-positive results. Further large-scale prospective cohort studies are needed to select the most sensitive and specific circulating RNA panels. 
1. Qiu J, Xu J, Zhang K, Gu W, Nie L. Refining Cancer Management Using Integrated Liquid Biopsy. Theranostics. 2020; 10 (5): 237484. DOI: $10.7150 /$ thno.40677.

2. Shen J, Kong W, Wu Y, Ren H, Wei J, Yang Y, et al. Plasma mRNA as liquid biopsy predicts chemo-sensitivity in advanced gastric cancer patients. J Cancer. 2017; 8 (3): 434-2. DOI: 10.7150/ jca.17369.

3. Perakis S, Speicher MR. Emerging concepts in liquid biopsies. BMC Med. 2017; 15 (1): 75.

4. Buder A, Tomuta C, Filipits M. The potential of liquid biopsies. Curr Opin Oncol. 2016; 28: 130-134.

5. Sozzi G, Conte D, Leon M, Ciricione R, Roz L, Ratcliffe C, et al. Quantification of free circulating DNA as a diagnostic marker in lung cancer. J Clin Oncol. 2003; 21: 3902-8.

6. Sozzi G, Musso K, Ratcliffe C, Goldstraw P, Pierotti MA, Pastorino U. Detection of microsatellite alterations in plasma DNA of non-small cell lung cancer patients: a prospect for early diagnosis. Clin Cancer Res. 1999. 5: 2689-92.

7. Egyud M, Sridhar P, Devaiah A, Yamada E, Saunders S, Ståhlberg A, et al. Plasma circulating tumor DNA as a potential tool for disease monitoring in head and neck cancer. Head Neck. 2019; 41 (5): 1351-8. DOI: 10.1002/hed.25563.

8. Kawakami K, Brabender J, Lord RV, Groshen S, Greenwald BD, Krasna MJ, et al. Hypermethylated APC DNA in plasma and prognosis of patients with esophageal adenocarcinoma. $\mathrm{JNCl}$ 2000; 92 (22): 1805-11. Available from: https://doi.org/10.1093/ jnci/92.22.1805.

9. Shaw JA, Smith BA, Walsh T, Johnson S, Primrose L, Slade MJ Microsatellite alterations plasma DNA of primary breast cancer patients. Clin Cancer Res. 2000; 6: 1119-24.

10. Kirk GD, Camus-Randon AM, Mendy M, Goedert JJ, Merle P, Trepo C, et al. Ser-249 p53 mutations in plasma DNA of patients with hepatocellular carcinoma from the Gambia. J Natl Cancer Inst (Bethesda). 2000; 92 (2): 148-53. DOI: 10.1093/jnci/92.2.148.

11. Koprenski MS, Benko FA, Borys DJ, Khan A, McGarrity TJ, Gocke C. D. Somatic mutation screening: identification of individuals harboring $\mathrm{K}$-ras mutations with the use of plasma DNA. J Natl Cancer Inst (Bethesda). 2000; 92: 918-23.

12. Yamada T, Nakamori S, Ohzato H, Oshima S, Aoki T, Higaki N. Detection of K-ras gene mutations in plasma DNA of patients with pancreatic adenocarcinoma: correlation with clinicopathological features. Clin Cancer Res. 1998; 4: 1527-32.

13. Goessl C, Heicappell R, Muncher R, Anker P, Stroun M, Krause H, et al. Microsatellite analysis of plasma DNA from patients with clear cell renal carcinoma. Cancer Res. 1998; 58: 4728-32.

14. Bryzgunova OE, Laktionov PP. Current methods of extracellular DNA methylation analysis. Molecular Biology. 2017; 51 (2): 16783 DOI: 10.1134/S0026893317010071.

15. Zhong $X Y$, Laivuori H, Livingston JC, Ylikorkala O, Sibai BM, Holzgreve W, et al. Elevation of both maternal and fetal extracellular circulating deoxyribonucleic acid concentrations in the plasma of pregnant women with preeclampsia. Am J Obstet Gynecol. 2001; 184 (3): 414-9. DOI: 10.1067/mob.2001.109594.

16. Zhong XY, Burk MR, Troeger C, Jackson LR, Holzgreve W, Hahn S. Fetal DNA in maternal plasma is elevated in pregnancies with aneuploid fetuses. Prenatal Diagn. 2000; 20 (10): 795-8.

17. Sekizawa A, Sugito Y, Iwasaki M, Watanabe A, Jimbo M, Hoshi S, et al. Cell-free fetal DNA is increased in plasma of women with hyperemesis gravidarum. Clin Chem. 2001; 47 (12): 2164-5.

18. Tong Y, Lo YM. Diagnostic developments involving cell-free (circulating) nucleic acids. Clin Chim Acta. 2006; 363: 187-96.

19. Pachot A, Blond J-L, Mougin B, Miossec P. Peptidylpropyl isomerase B (PPIB): a suitable reference gene for mRNA quantification in peripheral whole blood. Biotechnol. 2004; 114 (1-2): 121-4. DOI: 10.1016/j.jbiotec.2004.07.001.

20. Hasselmann DO, Rappl G, Rossler M, Ugurel S, Tilgen W, Reinhold U. Detection of tumor-associated circulating mRNA in serum, plasma and blood cells from patients with disseminated malignant melanoma. Oncol Rep. 2001; 8 (1): 115-8. DOl: 10.3892/or.8.1.115.

21. El-Hefnawy T, Raja S, Kelly L, Bigbee WL, Kirkwood JM, Luketich
JD, et al. Characterization of amplifiable, circulating RNA in plasma and its potential as a tool for cancer diagnostics. Clin Chem. 2004; 50: 564-73. DOI: 10.1373/clinchem.2003.028506.

22. Novakovic S, Hocevar M, Zgajnar J, Besic N, Stegel V. Detection of telomerase RNA in the plasma of patients with breast cancer, malignant melanoma or thyroid cancer. Oncology Reports. 2004; 11 (1): 245-52. DOI: 10.3892/or.11.1.245.

23. Dasi F, Lledo S, Garcia-Granero E, Ripoll R, Marugan M, Tormo M, et al. Real-time quantification in plasma of human telomerase reverse transcriptase (hTERT) mRNA: a simple blood test to monitor disease in cancer patients. Lab Invest. 2001; 81 (5): $767-$ 9. DOI: 10.1038/ labinvest.3780285.

24. Silva JM, Dominguez G, Silva J, Garcia JM, Sanchez A, Rodriguez O, et al. Detection of epithelial messenger RNA in the plasma of breast cancer patients is associated with poor prognosis tumor characteristics. Clin Cancer Res. 2001; 7 (9): 2821-5.

25. Perhavec A, Cerkovnik P, Novakovic S, Zgajnar J. The hTERT mRNA in plasma samples of early breast cancer patients, non-cancer patients and healthy individuals. Neoplasma. 2008; 55: 549-54.

26. Lee G-W, Kim J-Y, Koh E-H, Kang D, Choi DS, Maeng K-Y, et al. Plasma human mammaglobin mRNA associated with poor outcome in patients with breast cancer. Genet Mol Res. 2012; 11 (4): 4034-42. DOI: 10.4238/2012.November.28.2.

27. Silva J, García V, García JM, Peña C, Domínguez G, Díaz R, et al. Circulating Bmi-1 mRNA as a possible prognostic factor for advanced breast cancer patients. Breast Cancer Research. 2007; 9: R55.

28. Zhang K, Luo Z, Zhang Y, Wang Y, Cui M, Liu L, et al. Detection and Analysis of circulating large intergenic non-coding RNA regulator of reprogramming in plasma for breast cancer. Thorac Cancer. 2018; 9 (1): 66-74. DOI: 10.1111/1759-7714.12537.

29. Wong SC, Lo SF, Cheung MT, Ng KO, Tse CW, Lai BS, et al. Quantification of plasma beta-catenin mRNA in colorectal cancer and adenoma patients. Clin Cancer Res. 2004; 10 (5): 1613-7.

30. Abdelghany AM, Rezk NS, Osman MM, Hamid Al, Al-Breedy AM, Abdelsattar HA. Using Lamin B1 mRNA for the early diagnosis of hepatocellular carcinoma: a cross-sectional diagnostic accuracy study. F1000Res. 2018; 7: 1339. DOI: 10.12688/ f1000research.14795.1.

31. Fu X, Shen C, Li G, Zhang X, Wen Z. Quantitative detection of plasma level of human telomerase reverse transcriptase mRNA in patients with nasopharyngeal carcinoma. Journal of Southern Medical University. 2015; 35 (6): 894-7.

32. Leng $\mathrm{Q}$, Tsou J-H, Zhan M, Jiang F. Fucosylation Genes as Circulating Biomarkers for Lung Cancer. J Cancer Res Clin Oncol. 2018; 144 (11): 2109-15. DOI: 10.1007/s00432-018-2735-0.

33. Rainer TH, Lam NY, Tsui NB, Ng EK, Chiu RW, Joynt GM, et al. Effects of filtration on glyceraldehyde-3-phosphate dehydrogenase mRNA in the plasma of trauma patients and healthy individuals. Clin Chem. 2004; 50 (1): 206-8. DOI: 10.1373/ clinchem.2003.022533.

34. Atamaniuk J, Vidotto C, Tschan H, et al. Increased concentrations of cell-free plasma DNA after exhaustive exercise. Clin Chem. 2004; 50: 1668-70.

35. Hamaoui K, Butt A, Powrie J, Swaminathan R. Realtime quantitative PCR measurement of circulatory rhodopsin mRNA in healthy subjects and patients with diabetic retinopathy. Ann N Y Acad Sci. 2004; 1022: 152-6. DOI: 10.1196 / annals.1318.025.

36. Tsui NB, Chim SS, Chiu RW, Lau TK, Ng EK, Leung TN, et al. Systematic micro-array based identification of placental mRNA in maternal plasma: towards non-invasive prenatal gene expression profiling. J Med Genet. 2004; 41: 461-7. DOI: 10.1136/ jmg.2003.016881.

37. HuX, LiD, Zhang W, Zhou J, Tang B, LiL. Matrix metalloproteinase-9 expression correlates with prognosis and involved in ovarian cancer cell invasion. Archives of Gynecology and Obstetrics. 2012; 286 (6): 1537-43. DOI: 10.1007/s00404-012-2456-6.

38. Galdiero F, Romano A, Pasquinelli R, Pignata S, Greggi S, Vuttariello $E$, et al. Detection of high mobility group A2 specific mRNA in the plasma of patients affected by epithelial ovarian cancer. Oncotarget. 2015; 6 (22): 19328-35. DOI: 10.18632/ 
oncotarget.2896.

39. Deligezer U, Yaman F, Darendeliler E, Dizdar Y, Holdenrieder S, Kovancilar M, et al. Post-treatment circulating plasma BMP6 mRNA and H3K27 methylation levels discriminate metastatic prostate cancer from localized disease. Clinica Chimica Acta. 2010; 411 (19-20): 1452-6. DOI: 10.1016/i.cca.2010.05.040.

40. March-Villalba JA, Martínez-Jabaloyas JM, Herrero MJ, Santamaría J, Aliño SF, Dasí F. Plasma hTERT mRNA discriminates between clinically localized and locally advanced disease and is a predictor of recurrence in prostate cancer patients. Expert Opin Biol Ther. 2012; 12: 69-77. DOI: 10.1517/14712598.2012.685716.

41. Peinado $\mathrm{H}$, et al. Melanoma exosomes educate bone marrow progenitor cells toward a pro-metastatic phenotype through MET. Nat Med. 2012; 18: 883-91.

42. Hoshino A, Costa-Silva B, Shen T-L, Rodrigues G, Hashimoto A, Mark MT, et al. Tumour exosome integrins determine organotropic metastasis. Nature. 2015; 527 (7578): 329-35. DOI: 10.1038/ nature15756.

43. Colombo M, Raposo G, Thery C. Biogenesis, secretion, and intercellular interactions of exosomes and other extracellular vesicles. Annu Rev Cell Dev Biol. 2014; 30: 255-89. DOI: 10.1146/annurev-cellbio-101512-122326.

44. van Niel G, D'Angelo G, Raposo G. Shedding light on the cell biology of extracellular vesicles. Nat Rev Mol Cell Biol. 2018; 19 (4): 213-28. DOI: 10.1038/nrm.2017.125.

45. Shah R, Patel T, Freedman JE. Circulating extracellular vesicles in human disease. N Engl J Med. 2018; 379 (10): 958-66. DOI: 10.1056/NEJMra1704286.

46. Valadi H, Ekstrom K, Bossios A, Sjostrand M, Lee JJ, Lotvall JO. Exosome-mediated transfer of mRNAs and microRNAs is a novel mechanism of genetic exchange between cells. Na Cell Biol. 2007; 9 (6): 654-59. DOI: 10.1038/ncb1596.

47. Zhang J, Li S, Li L, Li M, Guo C, Yao J, Mi S. Exosome and exosomal microRNA: trafficking, sorting, and function. Genomics Proteomics Bioinformatics. 2015; 13 (1): 17-24. DOI: 10.1016/j. gpb.2015.02.001.

48. Li Y, Zhao J, Yu S, Wang Z, He X, Su Y, et al. Extracellular Vesicles Long RNA Sequencing reveals abundant mRNA, circRNA, and IncRNA in human blood as potential biomarkers for cancer diagnosis. Clin Chem. 2019; 65 (6): 798-808. DOI: 10.1373/ clinchem.2018.301291.

49. Bartel DP. MicroRNAs: genomics, biogenesis, mechanism, and function. Cell. 2004; 116 (2): 281-97. DOI: 10.1016/S00928674(04)00045-5.

50. Weber JA, Baxter DH, Zhang S, Huang DY, Huang KH, Lee MJ, et al. The microRNA spectrum in 12 body fluids. Clin Chem. 2010; 56 (11): 1733-41. DOI: 10.1373/clinchem.2010.147405.

51. Boon RA, Vickers KC. Intercellular transport of microRNAs. Arterioscler Thromb Vasc Biol. 2013; 33 (2): 186-92. DOI: 10.1161/ATVBAHA.112.300139.

52. Arroyo JD, Chevillet JR, Kroh EM, Ruf IK, Pritchard CC, Gibson DF, et al. Argonaute2 complexes carry a population of circulating microRNAs independent of vesicles in human plasma. Proc Natl Acad Sci USA. 2011; 108 (12): 5003-8. DOI: 10.1073/ pnas. 1019055108

53. Vickers KC, Palmisano BT, Shoucri BM, Shamburek RD, Remaley AT. MicroRNAs are transported in plasma and delivered to recipient cells by high-density lipoproteins. Nat. Cell Biol. 2011; 13: 42333. DOI: $10.1038 / \mathrm{ncb} 2210$.

54. Van Eijndhoven MA, Zijlstra JM, Groenewegen NJ, Drees EE, van Niele S, Baglio SR, et al. Plasma vesicle miRNAs for therapy response monitoring in Hodgkin lymphoma patients. JCl Insight. 2016; 1 (19): e89631. DOI: 10.1172/jci.insight.89631.

55. Watahiki A, Macfarlane RJ, Gleave ME, Crea F, Wang Y, Helgason CD, et al. Plasma miRNAs as biomarkers to identify patients with castration-resistant metastatic prostate cancer. Int J Mol Sci. 2013; 14 (4): 7757-70. DOI: 10.3390/ijms14047757.

56. Shen W, Song M, Liu J, Qiu G, Li T, Hu Y, et al. MiR-26a Promotes Ovarian Cancer Proliferation and Tumorigenesis. PLoS One. 2014; 9 (1): e86871. DOI: 10.1371/journal.pone.0086871.

57. Cuk K, Zucknick M, Heil J, Madhavan D, Schott S, Turchinovich A, et al. Circulating microRNAs in plasma as early detection markers for breast cancer. International Journal of Cancer. 2013; 132 (7): 1602-12. Available from: https://DOI.org/10.1002/ijc.27799.

58. Ng EK, Li R, Shin VY, Jin HC, Leung CP, Ma ES, et al. Circulating microRNAs as specific biomarkers for breast cancer detection. PLoS One. 2013; 8 (1). DOl: 10.1371/journal.pone.0053141.

59. Müllauer L. Next generation sequencing: Clinical applications in solid tumours. Memo. 2017; 10 (4): 244-7. DOI: 10.1007/ s12254-017-0361-1.

60. Giuffrida MC, Spoto $G$. Integration of isothermal amplification methods in microfluidic devices: Recent advances. Biosens Bioelectron. 2017; 90: 174-86. DOI: 10.1016/j.bios.2016.11.045.

61. Giuffrida MC, Zanoli LM, D'Agata R, Finotti A, Gambari R, Spoto G. Isothermal circular-strand-displacement polymerization of DNA and microRNA in digital microfluidic devices. Anal Bioanal Chem. 2015; 407 (6): 1533-43. DOI: 10.1007/s00216-014-8405-4.

62. Alix-Panabieres $\mathrm{C}$, Pantel K. Challenges in circulating tumour cel research. Nat Rev Cancer. 2014; 14 (9): 623-31. DOI: 10.1038/ nrc3820.

\section{Литература}

1. Qiu J, Xu J, Zhang K, Gu W, Nie L. Refining Cancer Management Using Integrated Liquid Biopsy. Theranostics. 2020; 10 (5): 2374 84. DOI: 10.7150/thno.40677.

2. Shen J, Kong W, Wu Y, Ren H, Wei J, Yang Y, et al. Plasma mRNA as liquid biopsy predicts chemo-sensitivity in advanced gastric cancer patients. J Cancer. 2017; 8 (3): 434-2. DOI: 10.7150/ jca.17369.

3. Perakis S, Speicher MR. Emerging concepts in liquid biopsies. BMC Med. 2017; 15 (1): 75

4. Buder A, Tomuta C, Filipits M. The potential of liquid biopsies. Curr Opin Oncol. 2016; 28: 130-134.

5. Sozzi G, Conte D, Leon M, Ciricione R, Roz L, Ratcliffe C, et al. Quantification of free circulating DNA as a diagnostic marker in lung cancer. J Clin Oncol. 2003; 21: 3902-8.

6. Sozzi G, Musso K, Ratcliffe C, Goldstraw P, Pierotti MA, Pastorino U. Detection of microsatellite alterations in plasma DNA of non-small cell lung cancer patients: a prospect for early diagnosis. Clin Cancer Res. 1999. 5: 2689-92.

7. Egyud M, Sridhar P, Devaiah A, Yamada E, Saunders S, Ståhlberg A, et al. Plasma circulating tumor DNA as a potential tool for disease monitoring in head and neck cancer. Head Neck. 2019; 41 (5): 1351-8. DOI: 10.1002/hed.25563.

8. Kawakami K, Brabender J, Lord RV, Groshen S, Greenwald BD,

Krasna MJ, et al. Hypermethylated APC DNA in plasma and prognosis of patients with esophageal adenocarcinoma. JNCl. 2000; 92 (22): 1805-11. Available from: https://doi.org/10.1093/ jnci/92.22.1805.

9. Shaw JA, Smith BA, Walsh T, Johnson S, Primrose L, Slade MJ. Microsatellite alterations plasma DNA of primary breast cancer patients. Clin Cancer Res. 2000; 6: 1119-24.

10. Kirk GD, Camus-Randon AM, Mendy M, Goedert JJ, Merle P, Trepo C, et al. Ser-249 p53 mutations in plasma DNA of patients with hepatocellular carcinoma from the Gambia. J Natl Cancer Inst (Bethesda). 2000; 92 (2): 148-53. DOI: 10.1093/inci/92.2.148.

11. Koprenski MS, Benko FA, Borys DJ, Khan A, McGarrity TJ, Gocke C. D. Somatic mutation screening: identification of individuals harboring K-ras mutations with the use of plasma DNA. J Natl Cancer Inst (Bethesda). 2000; 92: 918-23.

12. Yamada T, Nakamori S, Ohzato H, Oshima S, Aoki T, Higaki N. Detection of K-ras gene mutations in plasma DNA of patients with pancreatic adenocarcinoma: correlation with clinicopathological features. Clin Cancer Res. 1998; 4: 1527-32.

13. GoessI C, Heicappell R, Muncher R, Anker P, Stroun M, Krause H, et al. Microsatellite analysis of plasma DNA from patients with clear cell renal carcinoma. Cancer Res. 1998; 58: 4728-32.

14. Bryzgunova OE, Laktionov PP. Current methods of extracellular 
DNA methylation analysis. Molecular Biology. 2017; 51 (2): $167-$ 83 DOI: 10.1134/S0026893317010071.

15. Zhong $\mathrm{XY}$, Laivuori $\mathrm{H}$, Livingston JC, Ylikorkala O, Sibai BM, Holzgreve W, et al. Elevation of both maternal and fetal extracellular circulating deoxyribonucleic acid concentrations in the plasma of pregnant women with preeclampsia. Am J Obstet Gynecol. 2001; 184 (3): 414-9. DOI: 10.1067/mob.2001.109594.

16. Zhong XY, Burk MR, Troeger C, Jackson LR, Holzgreve W, Hahn S. Fetal DNA in maternal plasma is elevated in pregnancies with aneuploid fetuses. Prenatal Diagn. 2000; 20 (10): 795-8.

17. Sekizawa A, Sugito Y, Iwasaki M, Watanabe A, Jimbo M, Hoshi S, et al. Cell-free fetal DNA is increased in plasma of women with hyperemesis gravidarum. Clin Chem. 2001; 47 (12): 2164-5.

18. Tong Y, Lo YM. Diagnostic developments involving cell-free (circulating) nucleic acids. Clin Chim Acta. 2006; 363: 187-96.

19. Pachot A, Blond J-L, Mougin B, Miossec P. Peptidylpropyl isomerase $\mathrm{B}$ (PPIB): a suitable reference gene for mRNA quantification in peripheral whole blood. Biotechnol. 2004; 114 (1-2): 121-4. DOI: 10.1016/j.jbiotec.2004.07.001

20. Hasselmann DO, Rappl G, Rossler M, Ugurel S, Tilgen W, Reinhold U. Detection of tumor-associated circulating mRNA in serum, plasma and blood cells from patients with disseminated malignant melanoma. Oncol Rep. 2001; 8 (1): 115-8. DOl: 10.3892/or.8.1.115.

21. El-Hefnawy T, Raja S, Kelly L, Bigbee WL, Kirkwood JM, Luketich $\mathrm{JD}$, et al. Characterization of amplifiable, circulating RNA in plasma and its potential as a tool for cancer diagnostics. Clin Chem. 2004; 50: 564-73. DOI: 10.1373/clinchem.2003.028506.

22. Novakovic S, Hocevar M, Zgajnar J, Besic N, Stegel V. Detection of telomerase RNA in the plasma of patients with breast cancer, malignant melanoma or thyroid cancer. Oncology Reports. 2004 11 (1): 245-52. DOI: 10.3892/or.11.1.245.

23. Dasi F, Lledo S, Garcia-Granero E, Ripoll R, Marugan M, Tormo M, et al. Real-time quantification in plasma of human telomerase reverse transcriptase (hTERT) mRNA: a simple blood test to monitor disease in cancer patients. Lab Invest. 2001; 81 (5): $767-$ 9. DOI: 10.1038/ labinvest.3780285

24. Silva JM, Dominguez G, Silva J, Garcia JM, Sanchez A, Rodriguez O, et al. Detection of epithelial messenger RNA in the plasma of breast cancer patients is associated with poor prognosis tumor characteristics. Clin Cancer Res. 2001; 7 (9): 2821-5.

25. Perhavec A, Cerkovnik P, Novakovic S, Zgajnar J. The hTERT mRNA in plasma samples of early breast cancer patients, non-cancer patients and healthy individuals. Neoplasma. 2008; 55: 549-54.

26. Lee G-W, Kim J-Y, Koh E-H, Kang D, Choi DS, Maeng K-Y, et al. Plasma human mammaglobin mRNA associated with poor outcome in patients with breast cancer. Genet Mol Res. 2012; 11 (4): 4034-42. DOI: 10.4238/2012.November.28.2.

27. Silva J, García V, García JM, Peña C, Domínguez G, Díaz R, et al. Circulating Bmi-1 mRNA as a possible prognostic factor for advanced breast cancer patients. Breast Cancer Research. 2007; 9: R55.

28. Zhang K, Luo Z, Zhang Y, Wang Y, Cui M, Liu L, et al. Detection and Analysis of circulating large intergenic non-coding RNA regulator of reprogramming in plasma for breast cancer. Thorac Cancer. 2018; 9 (1): 66-74. DOI: 10.1111/1759-7714.12537.

29. Wong SC, Lo SF, Cheung MT, Ng KO, Tse CW, Lai BS, et al. Quantification of plasma beta-catenin mRNA in colorectal cancer and adenoma patients. Clin Cancer Res. 2004; 10 (5): 1613-7.

30. Abdelghany AM, Rezk NS, Osman MM, Hamid Al, Al-Breedy AM, Abdelsattar HA. Using Lamin B1 mRNA for the early diagnosis of hepatocellular carcinoma: a cross-sectional diagnostic accuracy study. F1000Res. 2018; 7: 1339. DOI: 10.12688/ f1000research.14795.1.

31. Fu X, Shen C, Li G, Zhang X, Wen Z. Quantitative detection of plasma level of human telomerase reverse transcriptase mRNA in patients with nasopharyngeal carcinoma. Journal of Southern Medical University. 2015; 35 (6): 894-7.

32. Leng Q, Tsou J-H, Zhan M, Jiang F. Fucosylation Genes as Circulating Biomarkers for Lung Cancer. J Cancer Res Clin Oncol. 2018; 144 (11): 2109-15. DOI: 10.1007/s00432-018-2735-0.

33. Rainer TH, Lam NY, Tsui NB, Ng EK, Chiu RW, Joynt GM, et al. Effects of filtration on glyceraldehyde-3-phosphate dehydrogenase mRNA in the plasma of trauma patients and healthy individuals. Clin Chem. 2004; 50 (1): 206-8. DOI: 10.1373/ clinchem.2003.022533.

34. Atamaniuk J, Vidotto C, Tschan $\mathrm{H}$, et al. Increased concentrations of cell-free plasma DNA after exhaustive exercise. Clin Chem. 2004; 50: 1668-70.

35. Hamaoui K, Butt A, Powrie J, Swaminathan R. Realtime quantitative PCR measurement of circulatory rhodopsin mRNA in healthy subjects and patients with diabetic retinopathy. Ann N Y Acad Sci. 2004; 1022: 152-6. DOI: 10.1196 / annals.1318.025.

36. Tsui NB, Chim SS, Chiu RW, Lau TK, Ng EK, Leung TN, et al. Systematic micro-array based identification of placental mRNA in maternal plasma: towards non-invasive prenatal gene expression profiling. J Med Genet. 2004; 41: 461-7. DOI: 10.1136/ jmg.2003.016881.

37. HuX, LiD, Zhang W, Zhou J, Tang B, LiL. Matrix metalloproteinase-9 expression correlates with prognosis and involved in ovarian cancer cell invasion. Archives of Gynecology and Obstetrics. 2012; 286 (6): 1537-43. DOI: 10.1007/s00404-012-2456-6.

38. Galdiero F, Romano A, Pasquinelli R, Pignata S, Greggi S, Vuttariello $E$, et al. Detection of high mobility group A2 specific mRNA in the plasma of patients affected by epithelial ovarian cancer. Oncotarget. 2015; 6 (22): 19328-35. DOI: 10.18632/ oncotarget.2896.

39. Deligezer U, Yaman F, Darendeliler E, Dizdar Y, Holdenrieder S, Kovancilar M, et al. Post-treatment circulating plasma BMP6 mRNA and H3K27 methylation levels discriminate metastatic prostate cancer from localized disease. Clinica Chimica Acta. 2010; 411 (19-20): 1452-6. DOI: 10.1016/j.cca.2010.05.040.

40. March-Villalba JA, Martínez-Jabaloyas JM, Herrero MJ, Santamaría J, Aliño SF, Dasí F. Plasma hTERT mRNA discriminates between clinically localized and locally advanced disease and is a predictor of recurrence in prostate cancer patients. Expert Opin Biol Ther. 2012; 12: 69-77. DOI: 10.1517/14712598.2012.685716.

41. Peinado $\mathrm{H}$, et al. Melanoma exosomes educate bone marrow progenitor cells toward a pro-metastatic phenotype through MET. Nat Med. 2012; 18: 883-91.

42. Hoshino A, Costa-Silva B, Shen T-L, Rodrigues G, Hashimoto A, Mark MT, et al. Tumour exosome integrins determine organotropic metastasis. Nature. 2015; 527 (7578): 329-35. DOI: 10.1038/ nature15756.

43. Colombo M, Raposo G, Thery C. Biogenesis, secretion, and intercellular interactions of exosomes and other extracellular vesicles. Annu Rev Cell Dev Biol. 2014; 30: 255-89. DOI: 10.1146/annurev-celllbio-101512-122326.

44. van Niel G, D'Angelo G, Raposo G. Shedding light on the cell biology of extracellular vesicles. Nat Rev Mol Cell Biol. 2018; 19 (4): 213-28. DOI: 10.1038/nrm.2017.125.

45. Shah $R$, Patel $T$, Freedman JE. Circulating extracellular vesicles in human disease. N Engl J Med. 2018; 379 (10): 958-66. DOl: 10.1056/NEJMra1704286.

46. Valadi $\mathrm{H}$, Ekstrom K, Bossios A, Sjostrand M, Lee JJ, Lotvall JO. Exosome-mediated transfer of mRNAs and microRNAs is a novel mechanism of genetic exchange between cells. Na Cell Biol. 2007; 9 (6): 654-59. DOI: 10.1038/ncb1596.

47. Zhang J, Li S, Li L, Li M, Guo C, Yao J, Mi S. Exosome and exosomal microRNA: trafficking, sorting, and function. Genomics Proteomics Bioinformatics. 2015; 13 (1): 17-24. DOI: 10.1016/j. gpb.2015.02.001.

48. Li Y, Zhao J, Yu S, Wang Z, He X, Su Y, et al. Extracellular Vesicles Long RNA Sequencing reveals abundant mRNA, circRNA, and IncRNA in human blood as potential biomarkers for cancer diagnosis. Clin Chem. 2019; 65 (6): 798-808. DOI: 10.1373/ clinchem.2018.301291.

49. Bartel DP. MicroRNAs: genomics, biogenesis, mechanism, and function. Cell. 2004; 116 (2): 281-97. DOI: 10.1016/S00928674(04)00045-5.

50. Weber JA, Baxter DH, Zhang S, Huang DY, Huang KH, Lee MJ, et al. The microRNA spectrum in 12 body fluids. Clin Chem. 2010; 56 (11): 1733-41. DOI: 10.1373/clinchem.2010.147405.

51. Boon RA, Vickers KC. Intercellular transport of microRNAs. Arterioscler Thromb Vasc Biol. 2013; 33 (2): 186-92. DOI: 10.1161/ATVBAHA.112.300139. 
52. Arroyo JD, Chevillet JR, Kroh EM, Ruf IK, Pritchard CC, Gibson DF, et al. Argonaute2 complexes carry a population of circulating microRNAs independent of vesicles in human plasma. Proc Natl Acad Sci USA. 2011; 108 (12): 5003-8. DOI: 10.1073/ pnas. 1019055108

53. Vickers KC, Palmisano BT, Shoucri BM, Shamburek RD, Remaley AT. MicroRNAs are transported in plasma and delivered to recipient cells by high-density lipoproteins. Nat. Cell Biol. 2011; 13: 42333. DOI: 10.1038/ncb2210.

54. Van Eijndhoven MA, Zijlstra JM, Groenewegen NJ, Drees EE, van Niele S, Baglio SR, et al. Plasma vesicle miRNAs for therapy response monitoring in Hodgkin lymphoma patients. JCl Insight. 2016; 1 (19): e89631. DOI: 10.1172/jci.insight.89631.

55. Watahiki A, Macfarlane RJ, Gleave ME, Crea F, Wang Y, Helgason CD, et al. Plasma miRNAs as biomarkers to identify patients with castration-resistant metastatic prostate cancer. Int $\mathrm{J} \mathrm{Mol} \mathrm{Sci.}$ 2013; 14 (4): 7757-70. DOI: 10.3390/ijms14047757.

56. Shen W, Song M, Liu J, Qiu G, Li T, Hu Y, et al. MiR-26a Promotes Ovarian Cancer Proliferation and Tumorigenesis. PLoS One. 2014; 9 (1): e86871. DOI: 10.1371/journal.pone.0086871.
57. CukK, Zucknick M, Heil J, Madhavan D, Schott S, Turchinovich A, et al. Circulating microRNAs in plasma as early detection markers for breast cancer. International Journal of Cancer. 2013; 132 (7): 1602-12. Available from: https://DOl.org/10.1002/ijc.27799.

58. Ng EK, LiR, Shin VY, Jin HC, Leung CP, MaES, et al. Circulating microRNAs as specific biomarkers for breast cancer detection. PLoS One. 2013; 8 (1). DOI: 10.1371/journal.pone.0053141.

59. Müllauer L. Next generation sequencing: Clinical applications in solid tumours. Memo. 2017; 10 (4): 244-7. DOI: 10.1007/ s12254-017-0361-1.

60. Giuffrida MC, Spoto G. Integration of isothermal amplification methods in microfluidic devices: Recent advances. Biosens Bioelectron. 2017; 90: 174-86. DOI: 10.1016/j.bios.2016.11.045.

61. Giuffrida MC, Zanoli LM, D'Agata R, Finotti A, Gambari R, Spoto G. Isothermal circular-strand-displacement polymerization of DNA and microRNA in digital microfluidic devices. Anal Bioanal Chem. 2015; 407 (6): 1533-43. DOI: 10.1007/s00216-014-8405-4.

62. Alix-Panabieres $\mathrm{C}$, Pantel $\mathrm{K}$. Challenges in circulating tumour cell research. Nat Rev Cancer. 2014; 14 (9): 623-31. DOI: 10.1038/ nrc3820. 